\title{
Do Frugal and Reverse Innovation Foster Sustainability? Introduction of a Conceptual Framework
}

\author{
Alexander Brem \\ University of Erlangen-Nuremberg, Germany \\ Björn Ivens \\ University of Bamberg, Germany
}

\begin{abstract}
The fields offrugal and reverse innovation as well as sustainability and its management have received tremendous interest in recent times. However, there is little literature on how both fields are related to each other. Hence, this paper gives an overview of research in both areas and provides a view of the relationship between frugal and reverse innovation, sustainability management and performance constructs. The link between frugal and reverse innovation on the one hand and sustainability performance on the other hand is established through a differentiated perspective on dimensions representing different fields of sustainability management, i.e. the sustainability of resources used in value creation, the sustainability of the actual value creation processes, and the sustainability of the outcomes of value creation processes. Moreover, we also argue for a positive link between the three dimensions of sustainability management and a company's market performance.
\end{abstract}

Keywords: Frugal Innovation, Reverse and practice are given to foster future research in this area.

\section{INTRODUCTION}

$\Lambda$

fter years of hesitation, many businesses are now actively working towards improving their sustainability performance (Hopkins, 2009). Epstein and Roy (2001) posit that sustainability performance leads to favorable stakeholder reactions which, in turn, improves long term corporate financial performance. Business strategy is a key driver of sustainability performance (Epstein and Widener 2011). Innovation, in turn, is an important component of business strategy (Teece, 2010; Brem, 2008a). As a consequence, the link between innovation and sustainability has received increasing attention. Today, arguably, "sustainability puts a normative demand on innovation to become more environmentally and socially benign and, at the same time, provides a new source of innovations and competitive advantage" (Hansen et al. 2009, p.685).

Several examples from companies headquartered in developed countries, such as General Electric's strategic initiative labeled "Ecomagination" (General Electric 2011) provide evidence that innovation and sustainability management are often closely intertwined today. Factors such as new

Journal of Technology

Management for Growing Economies

Vol. 4 No. 2 Oct 2013 pp. $31-50$

\section{CHITKARA}

C 2013 by Chitkara University. All Rights Reserved. 
Brem, A. Ivens, B. market opportunities from green technologies, external pressure from nongovernmental stakeholders, or the shift towards corporate citizenship and increasing attention to positions and scores in environmental rankings all push sustainability issues into the innovation process in Western multinational companies.

But what about developing countries? What role can sustainability play for businesses whose home base and/or strategic focus is on markets where customer demand and stakeholder pressure do not (yet) provide similar incentives for a new and sustainable look at innovation? Thus far, sustainable development has not been the primary focus in growth strategies formulated by companies from developing countries. However, with increasing environmental issues in countries such as China, India, Russia, or Brazil, and with local governments' augmented political concern about the way how companies based in their countries go about their business, sustainability management starts to receive more managerial attention from firms in developing countries as well.

How realistic, however, is a generic strategic reorientation among businesses from developing countries with respect to sustainability? It has long been argued that adopting a sustainability orientation and turning a company into a sustainable business inevitably leads to additional costs (Hopkins 2009, Nidumolu et al.2009). It has also been suggested that, notwithstanding a certain level of environmental consciousness, fostering practices of sustainable management in developing countries is particularly difficult because of the cost barrier. The classical assumption is that companies located in low cost countries need to focus on cost efficiency in order to ensure competitive advantage on markets characterized by low purchasing power and on which customers do not perceive value in sustainable products, production, logistics, and the like (e.g. Cacho et al, 2005).

In this paper, we argue that this classical view on sustainability and developing markets is overly simplistic. Emerging economy firms, which traditionally have played a secondary role in the global innovation landscape, have now begun to catch up in developing their own innovative capabilities (Brem, 2008b).

As a result, the number of innovations developed in emerging economies increased dramatically, especially by subsidiaries of MNCs (Zeschky et al, 2011). Firms in the emerging economies can learn from and catch up with investing multinationals, but to do so they need to develop their own innovative capabilities and move from a process to a product focus and from imitation to innovation (Li and Kozhikode, 2009; Brem and Moitra, 2012). With this new strategy approach many emerging economy firms are deploying their earnings to invest in R\&D as well as to acquire firms overseas to gain access to

Journal of Technology Management for Growing Economies, Volume 4, Number 2, Oct 2013 
sophisticated technological capabilities. These companies are using this unique situation to consider aspects of sustainability management, as concepts like frugal innovation are not just about redesigning products; but about rethinking entire company processes and business models.

For this, we propose an integrated view on sustainability and new forms of innovation, such as reverse or frugal innovation. Both issues tied together offer a strategic opportunity for companies from developing countries to integrate sustainability into their value creation processes. By doing so, we link two streams of literature that have rarely been discussed together in the past, writings on innovation management in developing countries and literature on sustainability management.

The remainder is structured as follows. First, we provide an overview of the changing role developing countries play in the field of innovation. Second, we review the two fundamental streams of literature we intend to integrate. Next, we develop a conceptual framework describing how frugal innovation allows companies from developing countries to implement measures of sustainability management. We close with a discussion of our framework as well as a series of avenues for future research.

\section{THE EVOLVING ROLE OF DEVELOPING COUNTRIES IN INNOVATION}

In the last years, there has been a substantial shift in the global innovation landscape towards international dispersion of innovation activities (Gerybadze and Reger 1999; Kumar 1998). As an example, Multinational Corporations (MNCs) answered the question of their preferred prospective international R\&D location in the year 2012, that they prefer China (62\%), the United States (41\%) and India (29\%) (UNCTAD 2005).

Now, after two decades; practicing and expanding in developing markets where labor is cheap, and fast-growing markets easily accessible, has become a mundane and normal process for MNC's (Khanna and Krishna, 2010). In addition now there is a trend that emerging economy firms, which traditionally played a secondary role in the global innovation landscape, have now begun to catch up in developing their own innovative capabilities (Jiatao and Rajiv 2009; Gerybadze and Reger 1999; Kumar 1998). The western companies entered the emerging markets thinking, companies can harvest the fruits of the R\&D and innovation skills painstakingly developed in their home countries (Brown and Hagel 2005). On the contrary, there are already several examples of successful and unsuccessful technology transfers from Europe to Asia (Brem and Moitra, 2012). However now they are countering a reverse effect of their investments in developing countries and the exponential growth of these markets. There is 
Brem, A. Ivens, B.

a growing trend of companies from developing countries which invest their earned money from the last decades into joint ventures and acquisitions in companies of developed countries. For this, Indian and Chinese companies are setting up R\&D centers within their own geographies as well as in developed countries (Aggarwal 2000, Agarwal and Brem, 2012).

Well-known examples are Chinese companies, but also Indian companies are investing in western companies. On the one hand, foreign companies invested in 2006 about 11.1 billion USD in India, on the other hand, Indian companies spent about 23.1 billion USD for 168 acquisition in foreign countries (Rybak 2007). However, India is not in the list of most-favored locations of top 100 locations for MNCs (UNCTAD 2006).

Table 1 is a list of major and well known acquisitions by Indian and Chinese companies in the last decade. This is not an exhaustive list but it very well depicts the growing trend of expansion and acquisition of western companies from 2000 till now.

Table 1: India and China MNC's major acquisitions

\begin{tabular}{|c|c|c|}
\hline $\begin{array}{c}\text { Acquisition } \\
\text { Year }\end{array}$ & $\begin{array}{c}\text { Acquirer Company Name } \\
\text { (Country) }\end{array}$ & $\begin{array}{c}\text { Acquired Company Name } \\
\text { (Country) }\end{array}$ \\
\hline 2000 & Tata Tea (India) & Tetley (UK) \\
\hline 2002 & Asian Paints (India) & Berger International (Singapore) \\
\hline 2005 & Bharat Forge (India) & Federal Forge (USA) \\
\hline 2005 & Lenovo (China) & IBM Personal computing division \\
(USA)
\end{tabular}

Journal of Technology Management for Growing Economies, Volume 4, Number 2, Oct 2013 
Both these trends, namely acquisition outside the home country and internationalization of $R \& D$ are leading to an interesting trend of movement of technology and innovation from the developed to the developing countries.

\section{LITERATURE REVIEW}

The review of literature covers the theme of frugal and reverse innovation. It also covers aspects related with sustainable management.

\section{Frugal and Reverse Innovation}

The term innovation is a favorite topic of research for organizational theory (Brem, 2011), and increasingly in emerging markets as well (Petrick, 2011). The importance of innovation is reflected in the dramatic increase in literature that addresses the role, nature and measurement of innovation (e.g. Johannessen et al. 2001, Christensen et al. 2004, Govindarajan and Trimble 2005, Chandy et al. 2006, von Krogh and Raisch, 2009). Moreover, the term innovation is described as the best-known indicator of organizational competitive advantage (Drazin and Schoonhoven, 1996, Christensen 1997). Eighty of the Fortune 500 companies that have focused on organic growth through innovations have "earned handsome rewards" for their shareholders, compared to companies with lower rates of organic growth (von Krogh and Raisch, 2009). Till date, researchers have been talking about how the emerging countries earlier experienced innovation in developed countries in a form referred to as 'exnovation' which is the "reverse of innovation" which follows a bottom up approach deriving technology transfer through reverse engineering of distributed products from industrialized economies. Thus, instead of moving from research to distribution, technology in emerging economies moves in the reverse direction, from distribution to production to development to research (Gardner 2002).

A main result of this trend is called "Frugal Innovation" or "Reverse Innovation", which refers to products having extremely high cost advantages compared to existing solutions. They typically do not have sophisticated technological features, but meet the basic needs at a low-cost level by comparably high value for the customer (Zeschky et al. 2011, Agarwal and Brem, 2012). In this context, Hang et al. (2010, p. 26) state that "sustainable innovation in emerging contexts will require firms to attract the vast number of potential consumers at the bottom of the pyramid."

These kinds of innovation are already beginning to make themself felt in the West, for instance in health care. General Electric (GE) has developed a cheap ultrasound device, originally for the Chinese market. It has now become the basis of a global business, with eager customers in the developed as well 
Brem, A. Ivens, B.

as the developing world. A similar strategy is pursued by Siemens with their program named SMART (Agarwal and Brem, 2012). This trend is apparent in consumer goods, too. Nowadays, there are some other examples in the healthcare sector as well which are using these frugal principles (Economist, 2009). Haier, a Chinese consumer electronics company, has become the market leader in the West for cheap fridges. Most Western carmakers are producing small, inexpensive vehicles that have been influenced by the Tata Nano. Mahindra and Mahindra's nifty little tractors are popular with hobby farmers and gardeners in America. Based on frugal and reverse Innovation, nowadays companies from emerging countries even became MNCs (Hang et al. 2010).

Hence, these kinds of innovation are not just about redesigning existing products, but rethinking the whole product development process from the scratch, especially for MNCs (Economist, 2010a).

To date, there is a plethora of different notations for the term Frugal Innovation. This might be an explanation why it is difficult to ensure a common understanding. Such other notations are especially "Frugal Engineering", "Reverse Innovation" and "Constraint-based Innovation" (Saraf 2009, Economist 2010b). Even though the terms are commonly used in press (e.g. Howard 2011), there is less research done on this phenomenon yet - at least not published in scientific journals (based on research in a leading journal database, EBSCO).

In this context, some authors argue that Frugal Innovation is another name for "Jugaad". The goal of Jugaad is to develop a simple product with a high benefit on a low cost level, which is designed for poor people (Saraf, 2009). Hence, such solutions are typically based on imaginative problem solving rather than on technological inventions (e.g. Kingsnorth et al. 2011). In this context, Lacy (2011) argues that Frugal Innovation is a successor of Jugaad as this concept lacks taxonomy and discipline.

Gupta(2011) states that "frugal Innovation is a new management philosophy, which integrates specific needs of the bottom of the pyramid markets as a starting point and works backward to develop appropriate solutions which may be significantly different from existing solutions designed to address needs of up market segments" (p. 1).

Following Nunes and Breene (2011), we suggest to distinguish between frugal innovation as designing offerings specifically for low-income market segments, and reverse innovation as new products developed in emerging markets which are then modified for sale in developed countries. This distinction is important as reverse innovation is the main challenge for Western companies because research and development are increasingly important in developing markets whereas competition is then taking place worldwide 
(Singhal, 2011). In this definition, frugal innovations are "only" developed for their home countries, and not meant for worldwide distribution. On the contrary, reverse innovation has the goal to develop market-oriented products in and for emerging economies through globalized innovation teams, which are meant to be sold worldwide from the beginning (Immelt et al., 2009). Therefore the classical value creation approach of Western MNCs turns upside down, with a very high competitive level of future competition.

To perceive frugal and reverse innovation as approaches to develop simple and ecological products, processes, services and business models with a low input of resources, costs and environmental interventions (Gupta and Wang 2009), the boundaries of frugal and reverse innovation and sustainability are obvious. Based on our following literature review on sustainability management, we develop a conceptual framework for future research. As we argue for both frugal and reverse innovation as discussed before, we use both terms in the following.

\section{Sustainability Management}

The concept 'sustainable development' evolved out of the United Nations Conference on Environment and Development (UNCED) held in 1987. While most companies have long been concerned with sustaining profitability over time, sustainable development broadens their strategic focus to include additional objectives. An increasing number of companies move to adopting a more balanced, socially responsible attitude that has been referred to as "triple bottom line" view (Elkington, 1997) of their business. In this enlarged perspective, sustainability refers to the long-term maintenance of systems according to environmental, economic, and social considerations (Crane and Matten, 2004). Sustainable development is development that meets the needs of the present without compromising the ability of future generations to meet their own needs (WCED, 1987). While these rather general definitions have left much room for interpretation, several institutions have attempted to define sustainability more precisely for specific contexts. For example, Garvare and Johansson (2010) characterize organizational sustainability as an organization surviving in the long-term in a volatile and uncertain environment. In a similar manner, but with a different focus, the Institute of Manufacturing at the University of Cambridge (Jansson et al. 2000) has defined industrial sustainability as "conceptualisation, design, and manufacture of goods and services that meet the needs of the present generation while not diminishing economic, social, and environmental opportunity in the long term."

The practical implication of the sustainability concept for companies intending to broaden their set of corporate objectives according to the triple 
Brem, A. Ivens, B.

bottom line is that a sustainability management system (SMS) is required. Sustainability management began as both biological and socioeconomic concept in forest management in 18th century Europe. It aimed at maintaining lumber resources both in order to ensure future economic and social welfare for stakeholders (Heske, 1938, Sample and Sedjo, 1996). In the 20th century, in a different yet related perspective, many companies have implemented measures of philanthropy, stakeholder dialogues, ethic codes, social contracts, environmental management systems and the like (Frederick, 2008). However, many of these initiatives were fragmented, selective, and isolated from each other. Only more recently have holistic and comprehensive SMS emerged (Epstein and Roy, 2003, McElhaney et al., 2004). Today, an increasing number of companies use a modern SMS and have implemented organizational structures and procedures translating sustainability strategy into coordinated practice (Eilbirt and Parket 1973, Roy 2009).

Such management systems aim at integrating a company's strategic and operative sustainability activities, involving actors from different functional areas, hierarchical levels, and geographic entities as well as heterogeneous resources. Moreover, an SMS also comprises activities fostering coordination of sustainability activities in value chains and networks. An SMS's two guiding objectives are the effectiveness as well as the efficiency of corporate sustainability activities.

There are different tasks in sustainability management (e.g. Brandon, 1999, Rusinko, 2005, McElhaney et al., 2004; Porter and Kramer, 2006; Garvare and Johansson, 2009), such as, for example,

- Identify and prioritize sustainability aspects and impacts,

- Identify legal requirements related to sustainability concepts and evaluate compliance,

- Develop sustainability objectives and targets within each organizational function,

- Identify and deploy education and training to ensure awareness and competence,

- Regularly interact with stakeholders including regulators and the public,

- Routinely audit the organization's management system against the requirements stipulated in the SMS standard,

- Ensure that top management periodically reviews the SMS.

Quality management has been suggested to constitute a bridge to environmental sustainability in organizations (Rusinko 2005). Drawing upon a framework initially developed for the area of quality management in the health care sector by Donabedian $(1980,1988,2005)$, but which has been drawn upon in different disciplines of management (e.g. Tam 2007, Gonnering 2011), these tasks can

Journal of Technology Management for Growing Economies, Volume 4, Number 2, Oct 2013 
be grouped into three main dimensions that form the domain of a company's sustainability management: input resources, value activities, and outcomes. We further elaborate on these dimensions in the following section.

Do Frugal and Reverse Innovation

\section{DEVELOPMENT OF A CONCEPTUAL FRAMEWORK}

\section{Derivation of variables}

Drawing upon both the literature on innovation management and the literature on sustainability management, we now develop and present a framework describing how frugal and reverse innovation are contributing to improvements in the areas of input resources, value activities, and outcomes, and how, in turn, it allows achieving increased sustainability performance as well as market performance, based on a sustainability management system (SMS).

Our starting point is the concept of sustainability management. Sustainability management can be conceived as a domain comprising three dimensions through which it allows a company to improve its triple bottom line: input resources, value activities, and outcomes.

- Input resources: Value creation requires input. Input takes the form of resources and capabilities (Wernerfelt 1984, Barney 1991, H kansson and Snehota 1995, Hunt and Morgan 1995), or more precisely, the services that a resource can render (Penrose 1959). Resources can be material or immaterial (Hunt 2000), operand or operant (Vargo and Lusch 2004). Companies need to ensure that all resources used directly or indirectly in value creation processes respect sustainability requirements. For example, raw materials, such as lumber, petrol, iron ore, and the like, all imply problems from a sustainability vantage point (e.g. Fromartz 2009). Their stock available is limited and making them available for value creation often has a huge impact on the environment, local communities etc. An SMS aims at reducing the amount of resources required for the production of a service or good, or at replacing rare and limited resources by other, more sustainable input factors. For example, rare earths used in the production of smart phones represent a major challenge in the area of input resources in a SMS.

- Value activities: Along with resources, value activities constitute an essential element of business (e.g. H kansson and Snehota 1995). The economics literature provides conceptual evidence relating to the fact that value creation can have positive and negative effects for third parties not directly involved. These effects are referred to as externalities (Baumol 1972). Negative external effects are also referred to as external costs which need to be interpreted in a broad sense and include not only monetary 
Brem, A. Ivens, B.

expenses but also all kinds of other reductions in wealth or quality of life. There exist, for example, external costs (or externalities) in the form of lost time, noise, health issues, and so forth. Such external costs can be considered unethical as they are traditionally not included in cost or harm calculations or prices used in market exchanges. Hence, other actors will need to support these costs (e.g. by enduring certain harm), without enjoying potential benefits from the value created. A company's value activities, such as inbound logistics, manufacturing, or marketing (Porter 1996), may have external effects. Lesser the negative external effects value activities have on stakeholders and nature, the more sustainable the value activities are.

An SMS aims at reducing external effects by identifying ways of reconfiguring or replacing value chains so as to reduce emission levels, avoid child labor, and the like. For example, carbon emissions from automotive manufacturing plants represent a major sustainability challenge in the area of value activities.

- Outcomes: Value activities are conducted in order to produce outcomes in the form of market offerings (Hunt, 2000). Hunt and Morgan (1995) argue that firms will achieve superior financial value if their market offerings allow them to occupy marketplace positions of competitive advantage. As these authors describe in their competitive position matrix, such a position can be occupied if outcomes of value creation activities (i.e. market offerings) (1) are perceived by some market segments to have superior value as compared to competitor offerings and/or (2) are produced at lower costs (Hunt and Morgan, 1995). In a classical perspective, companies have had little if any responsibilities for external effects caused by their market offerings once these have been sold. In a triple bottom line perspective, an SMS should aim at also limiting external effects of a company's services or products over the usage cycle until they are recycled or disposed. For example, carbon emissions from drivers and passengers using cars for transportation represent a major sustainability challenge in the area of outcomes.

These three dimensions form the heart of our conceptual framework. We posit that frugal and reverse innovation have the potential to help a company achieve improvements in each one of the three dimensions. We further argue that the higher the improvements on any one of these three dimensions, the better a company's sustainability performance. Moreover, we also expect improvements on all three dimensions to improve a company's market performance.

We outline these thoughts in more detail the following paragraphs with four propositions.

Journal of Technology Management for Growing Economies, Volume 4, Number 2, Oct 2013 


\section{PROPOSITIONS}

First, we argue that frugal and reverse innovation have the potential to help a company achieve sustainability improvements on all three dimensions outlined above. With respect to resources, frugal and reverse innovation have the potential to provide two contributions that will help a company improve its triple bottom line: (a) less resources required, (b) more sustainable resources used. Frugal and reverse innovation are implicating to design products in a simple yet functional way. As compared to existing products sold on developed markets, frugal and reverse innovation are aiming at creating simpler solutions for different markets at a comparable product advantage level. Functions or elements that are not necessary to insure that customers see basic value in the product are eliminated. For example, many mobile phones offer functions going clearly beyond the basic value expectations large customer groups have. By restraining functionalities to the core, fewer resources (material, human, logistics, etc.) are required when manufacturing the product. Moreover, by reanalyzing design elements used for developed markets, developers may find that they are able to replace input resources whose production, extraction etc. has a negative impact from a sustainability vantage point. Hence we formulate our first proposition:

P1: Frugal and reverse innovation allows reducing the amount and type of input resources required for the production of a market offering.

Value activities are the second dimension in sustainability management. The concept for a new, innovative market offering, such as a tangible product, has an impact on how sustainable the value creation process for that same offering is. It decides, for instance, how much energy is required in order to manufacture the product, but also to distribute it, to stock it, and the like. Because frugal and reverse innovation are reducing the complexity of market offerings, it can be expected to also reduce external effects of individual value activities. Hence:

P2: Frugal and reverse innovation allows reducing the complexity of value activities required in order to provide a market offering to potential customers.

The concept for an innovative market offering not only determines how the offering is going to be produced in the value creation process. It also determines the potential negative external effects that will occur during the usage cycle of the product as well as the impact at the end of the usage cycle. During the usage cycle, external effects can occur from numerous aspects such as gas emissions, noise emissions, negative health effects, and the like. At the end of the usage cycle, the major decision is whether the product will be recycled or refurbished, or whether it needs to be disposed. By simplifying the concept
Do Frugal and Reverse Innovation 
Brem, A. Ivens, B.

for a new market offering, frugal and reverse innovation can both reduce the amount of external effects during the usage cycle and at its end. At the end of the usage cycle, the fewer components a product consists of, the easier it is to either recycle or refurbish it or to dispose of it.

During the usage cycle, the relationship may be more complex. The reduction of potential external effects often requires additional equipment such as catalyzers, filters, and the like. If frugal and reverse innovation are leading to the elimination of components limiting external effects from a concept, it does not improve the triple bottom line. If, however, reverse engineering leads to simplified concepts that reduce other drivers of external effects, such as for example the size of a product or its weight, then it should lead to positive effects on the third dimension. Given that overall reverse engineering, when focusing on the right aspects, may help a company improve its triple bottom line, we propose:

P3: Frugal and reverse innovation allows reducing negative external effects that occur once customers start using the market offering they have purchased.

Furthermore, we posit that the more a company is able, through its SMS, to limit negative external effects of the input resources it requires, of the value activities it performs, and of the outcomes it produces, the more its sustainability performance improves. Sustainability performance can be defined as the extent to which an organization manages to achieve its sustainability objectives (Epstein and Roy 2003). Different approaches have been suggested in the literature in order to operationalize the concept of sustainability performance (e.g. Sethi 1975, Carroll 1979, Wood 1991). The rationale for the hypothesized link between the layers of sustainability management and sustainability performance is straightforward. The lower the negative external effects, the higher the sustainability performance.

P4: Higher the improvements initiated by company through frugal and reverse innovation on the three dimensions of SMS, higher will be its sustainability performance..

Finally, we posit that improvements on the three layers of sustainability management not only improve sustainability performance, but also market performance. Market performance "refers to the level of financial and competitive outcomes in the market, as are displayed in profit, return on investment, and market share" (Li and Calantone, 1998, p. 17). It can been operationalized with two judgmental indicators which are relative intraindustry measures, and with two objective measures, namely the firm`s actual share of the market served as well as the pretax profit margin ( $\mathrm{Li}$ and

Journal of Technology Management for Growing Economies, Volume 4, Number 2, Oct 2013 
Calantone, 1998). For further distinctions, measures like return of sales and on assets, growth in profit, sales and market share growth, cash flow, overall operational efficiency, or reputation may be used (De Luca and AtuaheneGima 2007). The rationale for the hypothesized effect is that reduced levels of input resources, more efficient value activities, and outcomes creating higher value for customers should increase a company's competitiveness through both, positive cost effects and increased sales revenues.

P5: Higher the degree of improvements a company achieves through frugal and reverse innovation on the three dimensions of SMS, higher will be the degree of market performance.

As a consequence, the traditional vantage point, held in both developing and emerging countries, according to which sustainability cannot and should not be a strategic priority for companies from developing countries is not valid. We argue that frugal and reverse innovation have the potential to help such businesses to improve both, their sustainability performance and their market performance. Our framework is summarized in figure 1.

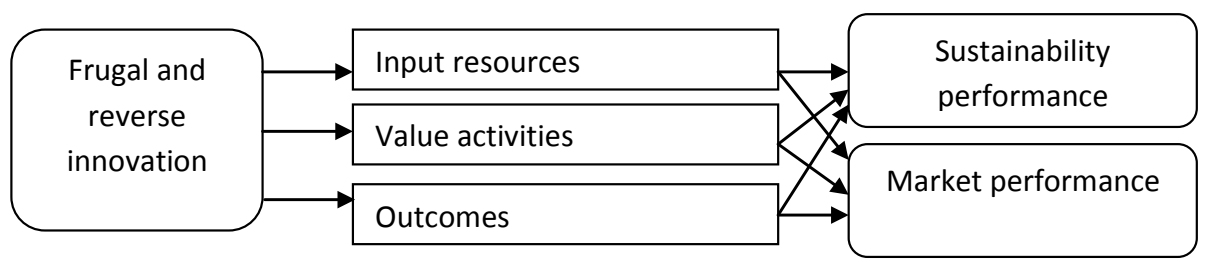

Figure 1: Conceptual framework

\section{CONCLUSION AND DIRECTIONS FOR FUTURE RESEARCH}

The striving for sustainable development needs an approach towards innovation that installs a balance of economical, ecological and social goals to be met (Vollenbroek 2002). Whereas in developed economies innovation processes have been reoriented in numerous companies already, in developing countries the shift is yet to come. Our conceptual framework provides a view of the relationship between frugal and reverse innovation and performance constructs. It suggests a causal chain that puts three dimensions of sustainability management at the intersection of frugal and reverse innovation and performance. The framework aims at the one hand to explain how frugal and reverse innovation can help companies from developing countries improve their sustainability performance. On the other hand, it gives insights for companies from developed countries how to react on these developments.

From a theoretical perspective, the framework establishes a link between an increasingly important concept in the field of innovation management, 
Brem, A. Ivens, B.

i.e. the frugal and reverse innovation approach, and constructs describing and measuring the company's performance in the area of sustainability management.

By doing so, it helps explain how innovation can contribute to improvements in sustainability performance, even when a company's home base is a developing country. The link between frugal and reverse innovation on the hand side and sustainability performance on the other is established through a differentiated perspective on dimensions representing different fields of sustainability management, i.e. the sustainability of resources used in value creation, the sustainability of the actual value creation processes, and the sustainability of the outcomes of value creation processes. To complete our framework, we also argue for a positive link between the three dimensions of sustainability management and a company's market performance.

With respect to innovation, before talking about future research, we strongly recommend determining commonly accepted definitions of the main terms frugal, reverse and constraint-based innovation. Hence, as discussed, research may follow Nunes and Breene`s (2011) distinguishing between frugal innovation as designing offerings specifically for low-income market segments, and reverse innovation as new products developed in emerging markets which are then modified for sale in developed countries. This is important as a common understanding of terms is the necessary basis for further scientific research. As this paper covered both areas, we used both terms at the same time.

Typically for early stage research, the little research which is available is based on case study research (e.g. Hang et al. 2010; Zeschky et al. 2011; Agarwal and Brem, 2012). As conceptual literature on frugal and reverse innovation is sparse so far, we want to initiate further research in this direction which should be based on the existing qualitative literature and on our introduced conceptual framework. Future case studies may consider if there are specific frugal and reverse innovation differences in the general product innovation process, $R \& D$ management, logistics or marketing, just to name a view. Moreover, we think that there are differences between small, medium and big companies, which should be paid attention to. As Hang et al. (2010) found that such companies from emerging countries became MNCs which started as entrepreneurs some years before, this might show interesting insights into alternative ways of company growth.

With this approach, we offer a basic structure for future quantitative research on frugal and reverse innovation as well. With the differentiation between input resources value activities, and outcomes we provide a differentiated structure 
of areas in which companies can achieve progress in sustainability. Extant frameworks (e.g. Epstein and Roy 2003) have drawn upon building blocks such as sustainability performance, which we acknowledge to be an important concept, and sustainability activities. They often make distinctions such as social sustainability activities and ecological sustainability activities, or they discuss sustainability with respect to different stakeholder groups. For the purpose of understanding the link between frugal and reverse innovation and sustainability performance, however, these perspectives provide limited help. Distinguishing between resources, processes, and outcomes, on the other hand, structures the issue in a manner that allows seeing that innovation management not only has an impact on outcome sustainability. It also determines which resources will be required and which processes employed. Hence, in designing a new product in a frugal resp. reverse perspective, companies are able to - but also need to understand that they need to - rethink more complex systems. Moreover, in the field of resources as well as processes, one company's research and development activities determine not only sustainability effects located within the boundaries of this one company. In today's networked economy, through supply chains and value creation networks frugal and reverse innovation will have an even larger impact. The innovating company determines the sustainability of its own operations as well as the sustainability of suppliers and cooperation partners. Hence, our framework allows not only discussing the innovation-sustainability link for one company, but also for larger groups of economic actors.

This point is not only interesting from a theoretical point of view where it indicates that companies' SMS must have a broad underlying view of the object of an SMS, i.e. a chain or network of activities jointly executed by different partners. It also has managerial implications. Through concepts such as frugal and reverse innovation, managers are able to influence the way in which their environment and partners exert external effects. Given that, particularly in developing countries, topics such as sustainability remain difficult to establish as a management objective most businesses adhere to, larger corporations in developing countries are able to show that they play a role of conscious corporate citizens by implementing frugal and reverse innovation and similar management concepts.

Furthermore, there is little empirical evidence concerning the innovationsustainability link. We suggest that future research could address several issues brought up by our framework. With respect to sustainability, one interesting question is to which extent improvements in the areas of resources, processes and outcomes have appositive effect on a company's sustainability performance. 
Brem, A. Ivens, B.

It is possible that contextual factors, such as industry sector, market complexity or market dynamics lead to different constellations where in one case improvements in the area of resources will have a strong impact on sustainability performance whereas in another the link could be weaker. Not explicitly included in our framework, it could also be argued that organizational culture or the organizational configuration of a company have an impact on the priorities it sets in sustainability management. In a similar vein, the value creation architecture, i.e. the constellation between insourced and outsourced value creation processes will likely lead to different emphases from one sustainability management system to another when it comes to improving the sustainability of resources, processes, and outcomes. A differentiation between Western companies and companies from developing countries, to research what differences there are in frugal and reverse innovation processes and outcomes, can be suggested. Another aspect is the correlation between a frugal and reverse innovation strategy and its outcome, measured as sustainability and market success.

Furthermore, cultural factors could lead to a stronger focus of companies from certain home countries on one dimension described above whereas the cultural environment in another country will lead companies with a home base such a country to different priorities. All of these aspects, in turn, will determine the market performance implications of sustainability management and future research could attempt to quantify the link.

Finally, it is important to bear in mind that frugal and reverse innovation are both partly based on political support which must be taken into consideration. Especially the "five-year plans of the People's Republic of China" show certain insights into public financed initiatives to build up innovation competencies. These influences must be taken into account in future research as well.

\section{REFERENCES}

Agarwal, N., Brem, A. Frugal and reverse innovation - Literature overview and case study insights from a German MNC in India and China, in: IEEE Xplore Proceedings of the 2012 18th International Conference on Engineering, Technology and Innovation, B. Katzy, T. Holzmann, K. Sailer, K. D. Thoben (Ed.), 2012, pp. 1-11. http://dx.doi.org/10.1109/ ICE.2012.6297683

Aggarwal, A. (2000) 'Deregulation, technology imports and in-house R\&D efforts: an analysis of the Indian experience, Research Policy, 29:9, p. http://dx.doi.org/1081-1093. 10.1016/ S0048-7333(99)00074-8.

Barney, J. (1991) 'Firm Resources and Sustained Competitive Advantage', Journal of Management, 17:1, pp. 99-120. http://dx.doi.org/10.1177/014920639101700108

Baumol, W.J., 1972. On taxation and the control of externalities. American Economic Review, 62:3, pp.307-322.

Brandon, P. S. (1999) 'Sustainability in Management and Organization', The Key Issues ?, Building Research \& Information, 27:6, pp. 390-396.

Journal of Technology Management for Growing Economies, Volume 4, Number 2, Oct 2013 
Brem, A. (2008a) 'The Boundaries of Innovation and Entrepreneurship - Conceptual Background and Essays on Selected Theoretical and Empirical Aspects, Gabler Verlag, Wiesbaden. http://dx.doi.org/10.1007/978-3-8349-9679-4

Brem, A. (2008b) 'The China Information Technology Handbook, in: Ordóñez De Pablos, P., Lytras, M. D. (Eds.), The China Information Technology Handbook, Springer US, pp. 433.

Brem, A. (2011) 'Linking innovation and entrepreneurship - literature overview and introduction of a process-oriented framework, International Journal of Entrepreneurship and Innovation Management, 14:1, pp. 6-35. http://dx.doi.org/10.1504/IJEIM.2011.040820.

Brem, A. and Moitra, D. (2012) 'Learning from Failure - Case Insights into a UK-India Technology Transfer Project, in: Audretsch, D.B.; Link, A.N.; Lehmann, E.E.; Starnecker, A. (Ed.): Technology Transfer in a Global Economy, International Handbook Series on Entrepreneurship, Edited by Audretsch, D.B. \& Acs, Z., Springer, Heidelberg, 2013, pp. 253-276. http://dx.doi.org/10.1007/978-1-4614-6102-9_14.

Brown, J.S. and Hagel J. (2005) 'Innovation blowback: Disruptive management practices from Asia, McKinsey Quarterly', 1, pp. 34-45.

Cacho, O.J., Marshall, G.R., and Milne, M. (2005) 'Transaction and abatement costs of carbonsink projects in developing countries, Environment \& Development Economics, 10 (5), 597-614. http://dx.doi.org/10.1017/S1355770X05002056.

Carroll, A.B. 1979, A Three-Dimensional Conceptual Mode of Corporate Performance. Academy of Management Review. 4:4, pp. 497-505. http://dx.doi.org/10.2307/257850.

Chandy, R., Hopstaken, B., Narasimhan, O. and Prabhu, J. (2006) 'From Invention to Innovation: Conversion Ability in Product Development', Journal of Marketing Research. 43:3, pp. 494-508. http://dx.doi.org/10.1509/jmkr.43.3.494.

Christensen, C. (1997) 'The innovator's dilemma: When new technologies cause great firms to fail, M.A', Harvard Business School Publishing Corporation, Boston.

Christensen, C., Scott, D. and Erik A. (2004) ,Seeing what's next”, M.A, Harvard Business School Publishing Corporation, Boston.

Crane, A., and Matten, D. (2004) 'Business Ethics: Managing Corporate Citizenship and Sustainability in the Age of Globalization', $2^{\text {nd }}$ edition, Oxford : University of Oxford Press.

De Luca, L.M. and Atuahene-Gima, K. (2007) Market Knowledge Dimensions and CrossFunctional Collaboration: Examining the Different Routes to Product Innovation Performance, Journal of Marketing, 71:1, pp. 95-112. http://dx.doi.org/10.1509/ jmkg.71.1.95

Donabedian, A. (1980) 'Explorations in Quality Assessment and Monitoring, Volume 1: The Definition of Quality and Approaches to Its Assessment', Ann Arbor : Health Administration Press.

Donabedian, A. (1988) 'The Quality of Care: How Can It Be Assessed?, The Journal of the American Medical Association, 260:12, pp. 1743-1748.

Donabedian, A. (2005) 'Evaluating the Quality of Medical Care, Milbank Quarterly, 83:4, pp. 691-729. http://dx.doi.org/10.1111/j.1468-0009.2005.00397.x.

Drazin, R. and Schoonhoven, C. B. (1996) 'Community Population \& Organization Effects on Innovation: A Multilevel Perspective', Academy of Management Journal, 39:5, pp. 10651083. http://dx.doi.org/10.2307/256992

Economist 2009: Health care in India: lessons from a frugal innovator, 4:18, pp. 69-70.

Economist, (2010a) First break all the rules, 395:8678, pp. 6-8.

Economist, (2010b) 'The power to disrupt, 395:8678, pp. 16-18.

Eilbirt, H. and Parker, I.R. (1973) 'The Corporate Responsibility Officer: A New Position on the Organization Chart, Business Horizons, February, pp. 45-51. http://dx.doi. org/10.1016/0007-6813(73)90060-8

Elkington, J. (1997) 'Cannibals with Forks: The Triple Bottom Line of 21st Century Business, 
Brem, A. Ivens, B.
Oxford : Capstone Publishing.

Epstein, M.J., Roy, M.-J. (2001) Sustainability in Action: Identifying and Measuring the Key Performance Drivers, Long Range Planning, 34:5, pp. 585-604. http://dx.doi.org/10.1016/ S0024-6301(01)00084-X.

Epstein, M.J. and Roy, M.-J. (2003) 'Making the Business Case for Sustainability: Linking Social and Environmental Actions to Financial Performance', Journal of Corporate Citizenship, 9, pp. 79-96.

Epstein, M.J. and Widener, S. K. (2011) 'Facilitating Sustainable Development Decisions: Measuring Stakeholder Reactions', Business Strategy and the Environment, 20, pp. 107123.

Frederick, W.C. (2008) 'Corporate Social Responsibility: Deep Roots, Flourishing Growth, Promising Future, in: Crane, A., McWilliams, A., Matten, D., Moon, J., Siegel, D.S. (Eds.), The Oxford Handbook of Corporate Social Responsibility. Oxford University Press, Oxford, pp. 522-531. http://dx.doi.org/10.1093/oxfordhb/9780199211593.001.0001.

Fromartz, S. (2009) '5 Companies, 5 Strategies, 5 Transformations', MIT Sloan Management Review, 51:1, pp. 41-45.

Gardner, P. L. (2002) 'The Globalization of R\&D and International Technology Transfer in the 21st Century, ICMIT \& ISMOT Conferences 18-20, October 2002, Hangzhou City.

Garvare, R. and Johansson, P. (2010) 'Management for sustainability - A stakeholder theory. Total Quality Management \& Business Excellence', 21:7, pp. 737-744. http://dx.doi.org/1 0.1080/14783363.2010.483095.

General Electric, 2011. General Electric Website, Retrieved from: http://www.ge.com/de/ unternehmen/ecomagination.html

Gerybadze, A. and Reger, G. (1999) 'Globalization of R\&D: recent changes in the management of innovation in transnational corporations', Research Policy, 28:2-3, pp. 251-274. doi:10.1016/S0048-7333(98)00111-5. http://dx.doi.org/10.1016/S0048-7333(98)00111-5.

Gonnering, R. S. (2011), The First Step, Quality Progress, 44:6, pp. 36-40.

Govindarajan, V. and Trimble, C. (2005) 'Organizational DNA for Strategic Innovation. California Management Review', 47:3, pp. 47-76.

Gupta, A. (2006) 'Emergence of Indian Multinationals', Technology Exports, 8:3, pp. 1-12.

Gupta, V.P., 2011. "Frugal Innovation”. The new masters of management, in: 'Jugaad' To Frugal Innovation. Indian MBA. Retrieved from: http://www.indianmba.com/Faculty_Column/ FC1283/fc1283.html, accessed: 09.01.2011.

Gupta, A.K. and Wang, H. (2009) 'Getting China and India right, Jossey- Bass/Wiley, San Francisco.

H kansson, H. and Snehota, I. (1995) 'Developing Relationships in Business Networks, Routledge, London.

Hansen, E.G., Grosse-Dunker, F. and Reichwald, R. (2009) 'Sustainability Innovation Cube - A Framework To Evaluate Sustainability-Oriented Innovations', International Journal of Innovation Management, 13:4, pp. 683-713. http://dx.doi.org/10.1142/ S1363919609002479.

Hang, C.C., Chen, J. and Subramian, A.M. (2010) 'Developing Disruptive Products for Emerging Economies: Lessons from Asian Cases', Research-Technology Management, 53:4, pp. 21-26

Heske, F. (1938) 'German Forestry, Yale University Press, New Haven.

Hopkins, M.S. (2009) '8 Reasons Sustainability Will Change Management, MIT Sloan Management Review, 51:1, pp. 27-30. http://dx.doi.org/10.1225/SMR328.

Howard, M. (2011) 'Will frugal innovation challenge the West? Market Leader Quarter', 3, pp. 53.

Hunt, S.D. (2000) 'A General Theory of Competition: Resources, Competences, Productivity,

Journal of Technology Management for Growing Economies, Volume 4, Number 2, Oct 2013 
Economic Growth, Sage Publications, Thousand Oaks.

Hunt, S. D. and Morgan, R.M. (1995) 'The Comparative Advantage Theory of Competition. Journal of Marketing, 59:1, pp. 1-15.

Immelt, J., Govindarajan, V. and Trimble, C. (2009) 'How GE is Disrupting Itself', Harvard Business Review, 10, pp. 56-65.

Jansson, P.M., Gregory, M.J., Barlow, C., Phaal, R., Farrukh, C.J.P., Probert, D.R. and So, V., (2000) 'Industrial Sustainability - A Review of UK and International Research and Capabilities, University of Cambridge, Cambridge.

Johannessen, J.-A., Olsen, B. and Lumpkin, G.T. (2001) 'Innovation as newness: what is new, how new, and new to whom? European Journal of Innovation Management, 4:1, pp. 20 31. http://dx.doi.org/10.1108/14601060110365547.

Jiatao, L. and Rajiv K.K. (2009) 'Developing new innovation models: Shifts in the innovation landscapes in emerging economies and implications for global R\&D management', Journal of International Management, 15:3, pp. 328-339. http://dx.doi.org/10.1016/j. intman.2008.12.005.

Khanna, T. and Krishna G.P. (2010) 'Winning in Emerging Markets: A Road Map for Strategy and Execution', Harvard Business Press, Harvard.

Kingsnorth, A.N., Tongaomkar, R.R. and Awojobi, O.A. (2011) 'Commentary on: low-cost mesh for inguinal hernia repair in resource-limited settings, in: Hernia Online FirstTM. 15, pp. 15-18. Retrieved from: http://www.springerlink.com/content/fr83v0v352627617/. http://dx.doi.org/10.1007/s10029-011-828-7.

Kronimus, A. and Roos, A. (2010) 'M\&A back to new reality, November Issue, The Boston Group, Boston.

Kumar, N. (1998) 'Technology Generation and Technology Transfers in the World Economy: Recent Trends and Implications for Developing Countries', Science Technology Society, 3:2, pp. 265-306. http://dx.doi.org/10.1177/097172189800300201.

Lacy, S. (2011) 'Brilliant, Crazy, Cocky. How the Top 1\% of Entrepreneurs profit from Global Chaos, Hoboken, New York.

Li, T. and Calantone, R.J. (1998) 'The Impact of Market Knowledge Competence on New Product Advantage: Conceptualization and Empirical Examination', Journal of Marketing, 62:4, pp. 13-29. http://dx.doi.org/10.2307/1252284.

Li, J., and Kozhikode, R.K. (2009) 'Developing new innovation models: Shifts in the innovation landscapes in emerging economies and implications for global R\&D management. Journal of International Management', 15:3, pp. 328-339. http://dx.doi.org/10.1016/j.intman.2008.12.005.

McElhaney, K., Toffel, M. and Hill, N. (2004) 'Designing a Sustainability Management System at BMW Group', Greener Management International, 46, pp. 103-116.

Nidumolu, R., Prahalad, C.K., and Rangaswami, M.R. (2009) 'Why Sustainability is Now the Key Driver of Innovation, Harvard Business Review, 87:9, pp. 56-64.

Nunes, P.F., Breene, T.S. (2011) 'Jumping the S-Curve. How to beat the growth cycle, get on top, and stay there', Harvard Business Review Press, Harvard.

Penrose, E.T. (1959) 'The Theory of the Growth of the Firm, Basil Blackwell and Mott', London.

Petrick, I.J. (2011) 'Innovation in Emerging Markets', Research Technology Management, 54:4, pp. 8-9.

Porter, M.E. (1996) 'What is Strategy? Harvard Business Review, 74, pp. 61-78.

Porter, M.E., and Kramer, M.R. (2006) 'Strategy and Society: The Link Between Competitive Advantage and Corporate Social Responsibility', Harvard Business Review, 84:12, pp. $78-92$.

Rybak, A. (2007) 'Indische Welteroberer, Financial Times Deutschland, 03.04.2007.

Roy, M.-J. (2009) 'Organizing for Corporate Social Performance: The Role of Board-Level 
Brem, A. Ivens, B.
Committees', Journal of Corporate Citizenship, 36, pp. 71-86.

Rusinko, C.A. (2005) 'Using Quality Management as a Bridge to Environmental Sustainability in Organizations', SAM Advanced Management Journal, 70:4, pp. 54-60. http://dx.doi. org/10.1108/14676370510623838.

Sample, V.A. and Sedjo, R.A. (1996) 'Sustainability in Forest Management, International Advances in Economic Research', 2:2, pp. 165-173.

Saraf, D. (2009) 'India's Indigenous Genius: Jugaad, in: The Wall Street Journal. Retrieved from: http://online.wsj.com/article/SB124745880685131765.html, accessed: 13.07.2009.

Sethi, S.P. (1975) 'Dimensions of Corporate Social Performance', California Management Review, 17:3, pp. 58-64.

Singhal, V. (2011) 'The Impact of Emerging Economies Innovative new models of global growth and vitality are emerging', Visions, 35:2, pp. 12-14.

Tam, J.L.M. (2007) 'Linking quality improvement with patient satisfaction: a study of a health service centre, Marketing Intelligence \& Planning, 25:7, pp. 732-745. http://dx.doi. org/10.1108/02634500710834197.

Teece, D.J. (2010) 'Business Models, Business Strategy and Innovation, Long Range Planning 43:2-3, pp. 172-194. http://dx.doi.org/10.1016/j.lrp.2009.07.003.

UNCTAD, 2005, World Investment Report - Transnational Corporations and the Internationalization of $\mathrm{R} \& \mathrm{D}$, New York.

UNCTAD, 2006. World Investment Report 2006 - FDI from Developing and Transition Economies, New York.

WCED, 1987. Our Common Future, Oxford University Press, Oxford.

Wernerfelt, B. (1984) 'A Resource-Based View of the Firm', Strategic Management Journal. 5:2, pp.171-180. http://dx.doi.org/10.1002/smj.4250050207.

Wood, D.J. (1991) 'Corporate Social Performance Revisited', Academy of Management Review’, 16:4, pp. 691-718. http://dx.doi.org/10.5465/AMR.1991.4279616.

Vargo, S.L. and Lusch, R.F. (2004) 'Evolving to a New Dominant Logic for Marketing, Journal of Marketing’, 68:1, pp. 1-17. http://dx.doi.org/10.1509/jmkg.68.1.1.24036.

Vollenbroek, F.A. (2002) 'Sustainable Development and the Challenge of Innovation', Journal of Cleaner Production, 10:3, pp. 215-224. http://dx.doi.org/10.1016/S0959-6526(01)000488.

Von Krogh G. and Raisch, S. (2009) Focus Intensely on a Few Great Innovation Ideas, Harvard Business Review, October 2009.

Zeschky, M., Widenmayer, B. and Gassmann, O. (2011) 'Frugal Innovation in emerging markets: the case of mettler', Research-Technology Management, 54:4, pp. 38-45. http:// dx.doi.org/10.5437/08956308X5404007.

Dr. Alexander Brem, University of Erlangen-Nuremberg, Germany.

Email: brem@idee-innovation.de.

Dr. Björn Ivens, University of Bamberg, Germany.

Email: bjoern.ivens@uni-bamberg.de.

Journal of Technology Management for Growing Economies, Volume 4, Number 2, Oct 2013 